New guidelines emerge from

\section{Pajaro Dunes}

\section{Washington}

Universities should only accept research funds from private companies if secrecy is kept to the absolute minimum necessary for patent protection. At the same time, companies which fund such research should normally be entitled to receive exclusive licences on any useful results that emerge, at least for a period sufficient to prevent rival companies from unfairly exploiting the same research.

These were two of the principal conclusions to emerge from a three-day meeting between the presidents and selected faculty members of five top US research universities, and senior executive officers of ten leading biotechnology companies, held at the California coastal resort Pajaro Dunes at the end of last week.

The conference had been organized largely at the suggestion of Dr Donald Kennedy, president of Stanford University. Its main purpose was to discuss a range of controversial issues that have emerged over the past few years as universities have looked to industry as an alternative source of research support from the federal government and have increased their efforts to push research results into the market-place. Companies in turn have been turning their attention to the frontiers of biomedical research in their quest for new and improved products and industrial processes.

Others attending the conference included the presidents of Harvard, Massachusetts Institute of Technology, University of California and California Institute of Technology. Each had been asked to invite one university administrator, two faculty members with direct or indirect experience of dealing with outside companies, and two senior executives from companies with experience of sponsoring university research. The companies represented at the meeting included Beckman Instruments, Syntex, Cetus Corporation, Applied Biosystems Inc., Gillette Corporation, Eli Lilly, DuPont and Genentech.

Dr Kennedy stressed after the meeting that the purpose had not been to agree on rigid rules that should apply to each university, but rather to work out what he described as a "framework for future relationships between universities and industry". Faculty members at several of the universities represented at Pajaro Dunes had already indicated their concern that it should be left to each university to

decide how broad principles should be interpreted into policy - a policy that last week's meeting was quick to endorse.

Nevertheless, criticism that the conference had been limited to senior administrators and scientists on both sides was expressed in a letter to the participants signed by 25 scientists at research universities across the country, as well as several prominent union and consumer spokesmen such as Anthony Mazzochi of the Oil Chemical and Atomic Workers, and Ralph Nader.

The letter invited the participants to attend a second conference later this summer, at which the same topics will be discussed but primarily from the point of view of groups both within and outside universities which felt they had been unfairly excluded from last week's meeting. The letter quoted from the final speech delivered by President Eisenhower, in which he criticized not only the growing power of the "military-industrial complex" but also the danger that important policy issues were increasingly

\title{
Flying start towards French law
}

The proposed French "research law", on which many of the plans of the minister for research and technology, Jean-Pierre Chevènement, depend, has cleared its first hurdle with a flying leap. The Economic and Social Council - a kind of litmus paper of the French nation - was not satisfied with giving mere approval to the law last week. Rather, it rearranged and added sentences to the draft bill to stress the significance of the new plans for France, indicating that they must be considered to be political priorities.

This is no slight thing, as the finance minister, Jacques Delors, recently put all spending ministries (including Chevènement's) on a tight rein. Something like a quarter of the new money offered to laboratories by Chevènement has had to be frozen, despite the minister's strong opposition. But, says the Economic and Social Council, "expenditure on research and development must escape, so far as is possible, from the present economic difficulties"'.

Money was not the only thing the council had in mind. Its members considered that the links between research and education need to be tightened; and so the council added phrases to the law which imply that Chevènement and the minister for national education, M. Alain Savary, must get together quickly to work something out, before Savary presents his own law to parliament in the autumn.

The council also stressed regionalization, sharpening the definition of the proposed "regional consultative committees" on research and technology. being decided by a scientific and technical elite, rather than through open democratic processes.

Dr Kennedy has already agreed to take part in this second conference. He also said on Saturday that he would help the organizers of the conference to raise the necessary funds.

The Pajaro Dunes meeting produced agreement on an 11-page statement which set out some principles as a basis from which individual universities can develop guidelines and codes of conduct. The statement stressed, for example, that although links should be encouraged between faculty members and outside companies since these were considered mutually beneficial, "professional relationships with commercial firms should not be allowed to interfere with responsibilities for teaching and research".

The statement also said that in general it was not appropriate for universities to own substantial equity in companies which were staffed by their own faculty members. This is a sensitive point at Harvard, which

It suggested words guaranteeing the mobility of personnel, and, in particular, emphasized the use of the French language in science. The use of French is "a fundamental objective" said the council, but admitted that it would be difficult to achieve. The research law should define a precise strategy, and the ministry should keep the council informed of progress on this issue, the council requested.

The broad support of the council for the research law will be welcome and significant, because the council is an important - if unusual - constitutional body. Its 200 members are drawn from all walks of life, but particularly from the working classes (as 140 members are supported by trades unions); and it gives its opinion and advice on such matters as are referred to it by the prime minister, or on matters that it chooses to study on its own behalf. Its advice is usually taken before major bills are put before the National Assembly, and although the advice is not binding, it would be politically inept to ignore it. Moreover, since the unions are strongly represented on the council, and since the same unions have a strong influence on the present socialist government, the council might be thought to have more weight than it had in the past.

The next ports of call for the draft law will be the Council of State (to check legality), the Council of Ministers (for final political approval by the government), and ultimately - perhaps by early summer the National Assembly for parliamentary debate, and, if successful, passage into law.

Robert Walgate 